\title{
Odbiorcy w kształtowaniu innowacyjności polskiego systemu przemystowego
}

\author{
Arkadiusz Świadek*, Barbara Czerniachowicz ${ }^{* *}$
}

Polska należy do krajów doganiajacych $z$ luka technologiczna szacowana na kilkadziesiąt lat. Wedtug danych GUS w przedsiębiorstwach przemystowych zarysowuje się tendencja do przewagi wdrożeń nowych procesów technologicznych nad produktami, co świadczy o specyfice preferencji krajowych podmiotów. Jednocześnie jest to kierunek odmienny, do tego, co obserwujemy w bardziej rozwiniętych krajach. W środowisku osób odpowiedzialnych za politykę krajowa i samorzadowa padaja sugestie czy wręcz zarzuty, że powinnismy zmierzać do oferowania rozwiązań będących wtaśnie rozwiąaniami krańcowymi w tańcuchu dostaw, a nie pośrednimi, które sa mało rozwojowe dla przedsiębiorstw. Powstaje zatem pytanie, czy $w$ krajowym systemie gospodarowania, na tym etapie rozwoju Polski, aktywność innowacyjna jest wyższa w przedsiębiorstwach, które oferuja swoje rozwiazania użytkownikowi finalnemu - detalicznemu, czy może $w$ tych, które funkcjonuja jedynie jako pośrednik, często $w$ międzynarodowym tańcuchu dostaw, będac tylko ogniwem $w$ skomplikowanych zależnościach produkcyjno-logistycznych. $W$ konsekwencji - czy krajowa polityka innowacyjna powinna $w$ dalszym ciagu wspierać tworzenie i przeptyw technologii do przedsiębiorstw, które sa poddostawcami nowych rozwiazań w tańcuchu dostaw, czy powinna być ukierunkowana na te tworzace gotowe rozwiazania dla krańcowego użytkownika. Warto zwrócić uwagę, że wnioski plynace z międzynarodowych badań wprost nakłaniaja do tworzenia instrumentów polityki innowacyjnej optymalnych w relacji do poziomu rozwoju technologicznego, czyli jego dystansu (odlegtości) do zjawisk obserwowanych u przywódców postępu światowego ze względu na zróżnicowane zdolności absorpcyjne.

Próba badawcza obejmuje 5209 przedsiębiorstw przemystowych w Polsce. Zastosowana metodyka bazuje na rachunku prawdopodobieństwa, a doktadnie modelowaniu typu probit (modele jednoczynnikowe) i logit (modele wieloczynnikowe).

Słowa kluczowe: innowacja, system, łańcuch dostaw, region, przemysł.

Nadesłany: 10.07.2015 | Zaakceptowany do druku: 28.09.2015

\section{Customers and the innovation activity of industrial system in Poland}

Poland is among the countries catching up with the technological gap estimated at several tens of years. According to the data obtained from GUS (Central Statistical Office), in industrial enterprises the implementation of new technological processes prevails over the products, which demonstrates the specificity of national preferences of entities. At the same time it is a different direction so as not to formulate the opposite view to what can be observed in more developed countries. Among those responsible for the national policy and local government

\footnotetext{
* Dr hab. prof. UZ Arkadiusz Świadek - Wydział Ekonomii i Zarządzania, Zakład Innowacji i Przedsiębiorczości, Uniwersytet Zielonogórski.

Adres do korespondencji: Uniwersytet Zielonogórski, Wydział Ekonomii i Zarządzania, Zakład Innowacji i Przedsiębiorczości, ul. Licealna 9, 65-417 Zielona Góra, e-mail: A.Swiadek@wez.uz.zgora.pl.

** Dr Barbara Czerniachowicz - Wydział Nauk Ekonomicznych i Zarządzania, Instytut Zarządzania i Inwestycji, Uniwersytet Szczeciński.

Adres do korespondencji: Uniwersytet Szczeciński, Wydział Nauk Ekonomicznych i Zarządzania, Instytut Zarządzania i Inwestycji, ul. Mickiewicza 69, 71-307 Szczecin, e-mail: b.czerniachowicz@wneiz.pl.
} 
suggestions or even complaints appear that we should strive to offer solutions that are marginal and not intermediate in the supply chain, which are a little development for businesses. Therefore, a question arises as to whether within a national system of management, at this stage of development of Poland, innovative activity is higher in companies that offer their solutions to the end-user - retailer, or perhaps to those that operate only as an intermediary, often in the international supply chain, being only the link in the complex relationships between production and logistics? As a consequence, should the national innovation policy continue to support the creation and transfer of technology to companies that are subcontractors of new solutions in the supply chain, or should it be targeted at those working out ready-made solutions for the end-user? It is worth noting that the conclusions drawn from the international research directly urge to create instruments of the innovation policy which is optimal in relation to the level of technological development i.e., its distance from the phenomena observed among the leaders in the world progress due to a different absorption capacity.

The reasearch sample comprises 5209 industrial enterprises in Poland. Methodology is based on probability theory, namely probit (univariate models) and logit models (multi-factor models).

Keywords: innovation system, supply chain, region, industry.

Submitted: 10.07.2015 | Accepted: 28.09.2015

JEL: E61, L16, O38, O31

\section{Wprowadzenie}

Państwa należące do światowej czołówki technologicznej kreują rozwiązania na bazie aktualnej wiedzy z danej dziedziny, co przekłada się na gotowe produkty sprzedawane później na rynku globalnym. Ich wysoki poziom technologiczny powoduje, że nowe rozwiązania kierowane są na rynek użytkowników finalnych (detalicznych). Oznacza to, że kraje rozwinięte o wysokiej kulturze technologicznej częściej wprowadzają nowe produkty niż procesy, a te sa $\mathrm{z}$ kolei tworzone w przedsiębiorstwach będących końcowym ogniwem w łańcuchu dostaw.

Polska zaliczana jest do krajów doganiających, charakteryzujących się luką technologiczną szacowaną na kilkadziesiąt lat (Geronikolaou i Mourmouris, 2015). Skutkuje to tym, że tylko w niewielkim zakresie uczestniczy w międzynarodowym handlu produktami wysokiej techniki. GUS szacuje, że w krajowym przemyśle występuje trend wzrostu wdrożeń nowych procesów technologicznych nad wyrobami, co określa preferencje i trendy przedsiębiorstw w Polsce (GUS, 2015). Jest to odmienny kierunek, niż można zaobserwować w bardziej rozwiniętych państwach. W politycznym środowisku - zarówno samorządowym, jak i krajowym - sugerowane są działania skłaniające przedsiębiorstwa do nastawienia na oferowanie rozwiązań krańcowych w łańcuchu dostaw, a nie tylko pośrednich. Można pokusić się tym samym o sformułowanie pytania, czy na tym etapie rozwoju Polski działalność innowacyjna jest wyższa w jednostkach kierujących swoje rozwiązania do odbiorcy finalnego (detalicznego), czy może w podmiotach funkcjonujących tylko jako pośrednik w łańcuchu dostaw. Wnioski, które można wyciągnąć z wyników międzynarodowych badań wskazują na konieczność tworzenia instrumentów polityki innowacyjnej, która będzie optymalna $\mathrm{w}$ relacji do poziomu rozwoju technologicznego, co oznacza konieczność jej zróżnicowania w Polsce z powodu niskich zdolności absorpcyjnych nowych technologii (Aghion i Jaravel, 2015).

Powyżej postawione pytanie jest związane $\mathrm{z}$ główną hipotezą badawczą, którą stanowi stwierdzenie, że aktywność innowacyjna w krajowym przemyśle jest wyższa w przedsiębiorstwach oferujących wyroby dla użytkownika finalnego niż półprodukty dla innych sektorów gospodarki, w tym jako do przemysłu.

Celem badania jest wskazanie szans na realizację różnych form aktywności innowacyjnej w krajowym przemyśle z perspektywy typu odbiorcy. 
Badanie zostało zrealizowane w przedsiębiorstwach przemysłowych zlokalizowanych w Polsce w latach 2007-2012 na grupie 5209 podmiotów. Przeprowadzono je, opierając się na bazie danych obejmującej ponad sześćdziesiąt tysięcy jednostek przemysłowych. Ze względu na zróżnicowaną skuteczność badania w poszczególnych województwach przyjęto w konsekwencji strukturę doboru przedsiębiorstw na podstawie wkładu (udziału) regionalnego, stosowanego przez Główny Urząd Statystyczny. Główną techniką badawczą było pozyskanie zbioru danych na podstawie przygotowanego kwestionariusza ankietowego, przy wykorzystaniu drogi telefonicznej oraz elektronicznej. Ze względu na brak dofinansowania badań autorzy sukcesywnie, w zależności od posiadanych zasobów, rozszerzali jego zakres na kolejne województwa, aż do momentu uzyskania oczekiwanej liczby wypełnionych formularzy ze wszystkich regionów. W konsekwencji zastosowano modelowanie statystyczne oparte na rachunku prawdopodobieństwa, które pozwoliło na ocenę i umożliwiło interpretację otrzymanych współzależności.

\section{Przegląd literatury}

Wiemy już od czasów Schumpetera (1934), że innowacje produktowe poddawane są ścisłej selekcji rynkowej, czyli decyzji o akceptacji bądź odrzuceniu przez użytkownika oferowanych rozwiązań (von Hippel, de Jong i Flowers, 2012). Wdrażanie nowych wyrobów na rynkach rozwiniętych przyśpiesza, podobnie jak proces ich inwencji i produkcji.

Współcześnie na świecie panuje dualizm badawczy w zakresie podejścia do wprowadzania na rynek nowych rozwiązań: 1) uwaga skupiona jest, w trakcie rozwoju produktu, na współzależności pomiędzy funkcjami takimi jak $\mathrm{B}+\mathrm{R}$, produkcja, marketing, nowe technologie (Griffin i Hauser, 1996; Adler, 1995), lub 2) poszukuje się szerokiego wachlarza związków kooperacji z różnorodnymi partnerami, przykładowo z klientami, dostawcami, jednostkami naukowymi, konkurentami czy dystrybutorami (Anderson i in., 1994; Gemunden i in., 1996; Hagedoorn, 1993).

Współpraca zewnętrzna może skutkować korzyściami, które polegają na bliskich relacjach z dostawcami i dzięki temu obniżają się koszty rozwoju nowych wyro- bów, głównie tych radykalnych, a zwiększa się tempo takiego postępu (Rothwell, 1994). Jeżeli celem jest wdrożenie radykalnie nowych produktów, to dostawcy oraz klienci powinni zostać mocno zaangażowani $\mathrm{w}$ te procesy (Laugen i Lassen, 2012). Współcześnie uważa się, że sieć jest dobrym miejscem do generowania innowacji, głównie dzięki dostępowi do komplementarnych zasobów i kompetencji (Powell i in., 1996). Podkreśla się przy tym współpracę międzyorganizacyjną, która może mieć wpływ na dostęp do tych komplementarnych aktywów oraz przyczynia się do efektywnego transferu wiedzy, a także podziału kosztów $\mathrm{B}+\mathrm{R}$ na poszczególnych uczestników. Organizacje, które angażują się w kooperację, częściej tworzą nowe produkty i doskonalą istniejące, a współpraca z różnymi podmiotami generuje zróżnicowane i bogate efekty innowacyjne (Faems $\mathrm{i}$ in., 2005). Na pozytywne relacje z klientami wpływa orientacja przedsiębiorstwa na klienta oraz konkurencję, a w mniejszym stopniu koordynacja funkcjonalna. Orientacja na konkurenta ma przy tym z kolei silny oraz pozytywny wpływ na poziom satysfakcji klienta (Guo i Wang, 2015).

Przedsiębiorstwa oparte na nowych technologiach, aby odpowiednio wdrażać innowacje, powinny opierać swoje działanie na inteligencji technologicznej oraz konkurencyjnej (Rodrigues i Riccardi, 2007). Te odpowiadają bowiem za stały dopływ informacji dla kadry menadżerskiej o zdolnościach organizacyjnych, otoczeniu konkurencyjnym, strategiach konkurencji, preferencjach odbiorców, trendach technologicznych czy w zakresie preferencji rynku (Suominen, Kytölä i Naaranoja, 2015).

Wartość dodana w łańcuchu wartości tworzona jest dzięki uwzględnieniu kierunku w dół (odbiorcy) oraz w górę (dostawcy) (Weinstein, 2012). Wertykalny łańcuch jest użytecznym modelem dla współczesnych organizacji, gdyż uwzględnia dużą liczbę podmiotów, które mają między sobą strategiczne i stabilne w czasie porozumienia (Weinstein, 2013). Odbiorcą w łańcuchu może być użytkownik detaliczny (B2C) lub inne przedsiębiorstwo (B2B). Różnice między nimi prezentuje tabela 1 .

Zarządzanie łańcuchem dostaw (SCM) jest związane $\mathrm{z}$ występowaniem sieci organizacji, które są pionowo powiązane w dół i w górę wieloma procesami oraz działa- 
Tabela 1. Klasyfikacja rynku z punktu widzenia typu konsumenta

\begin{tabular}{|c|c|c|}
\hline $\begin{array}{l}\text { Kryterium } \\
\text { porównania }\end{array}$ & Rynek B2C & Rynek B2B \\
\hline Końcowy konsument & $\begin{array}{l}\text { Konsument detaliczny } \\
\text { - osoba prywatna }\end{array}$ & Przedsiębiorstwa prywatne \\
\hline $\begin{array}{l}\text { Motywacja } \\
\text { konsumenta }\end{array}$ & $\begin{array}{l}\text { Emocjonalno- } \\
\text { racjonalna }\end{array}$ & Racjonalno-osobowościowa (Kotler, 2003) \\
\hline $\begin{array}{l}\text { Intensywność procesu } \\
\text { innowacyjnego }\end{array}$ & Bardzo wysoka & Wysoka lub średnia \\
\hline $\begin{array}{l}\text { Kluczowe czynniki } \\
\text { motywacji } \\
\text { konsumenta }\end{array}$ & $\begin{array}{l}\text { Emocjonalna chęć } \\
\text { zakupu } \\
\text { Subiektywna ewaluacja } \\
\text { wariantów }\end{array}$ & $\begin{array}{l}\text { Rozwiązanie zadań przedsiębiorstwa } \\
\text { Osobista motywacja związana z odpowiedzialno- } \\
\text { ścią i oczekiwaniem nagrody } \\
\text { Osobisty profesjonalizm sprzedawcy (Dixon } \\
\text { i Adamson, 2012) }\end{array}$ \\
\hline $\begin{array}{l}\text { Proces zakupowy } \\
\text { decyzja-realizacja }\end{array}$ & $\begin{array}{l}\text { Subiektywny, } \\
\text { spontaniczny }\end{array}$ & $\begin{array}{l}\text { Wielopoziomowy, hierarchiczny (The Differences } \\
\text { Between B2B and B2C Research, 2013) }\end{array}$ \\
\hline $\begin{array}{l}\text { Charakter } \\
\text { kluczowych } \\
\text { czynników } \\
\text { zakupowych }\end{array}$ & $\begin{array}{l}\text { Przedmiot podlega } \\
\text { emocjonalno-racjonal- } \\
\text { nej ewaluacji konsu- } \\
\text { menta w czasie zakupu }\end{array}$ & $\begin{array}{l}\text { Przedmiot odpowiada charakterystyce popytu na } \\
\text { produkt z wyważona ceną. } \\
\text { Subiektywna ewaluacja profesjonalizmu sprze- } \\
\text { dawcy (Boaz, Murnanen i Nuffer, 2012) }\end{array}$ \\
\hline $\begin{array}{l}\text { Cel marketingu } \\
\text { innowacji }\end{array}$ & $\begin{array}{l}\text { Formułowanie chęci } \\
\text { zakupu }\end{array}$ & $\begin{array}{l}\text { Wyszczególnienie powodów maksymalnie } \\
\text { korespondujących z czynnikami decydującymi } \\
\text { o zakupie }\end{array}$ \\
\hline $\begin{array}{l}\text { Model zachowań } \\
\text { konsumenta }\end{array}$ & $\begin{array}{l}\text { Model dyfuzji innowa- } \\
\text { cji (Rogers, 1983) }\end{array}$ & Model dwóch rynków (Moore i McKenna, 2006) \\
\hline
\end{tabular}

Źródło: Sekerin, Avramenko, Veselovsky i Aleksakhina (2014).

niami, których skutkiem jest wytwarzanie produktów i usług dostarczanych do finalnego klienta (Christopher, 2005). Istotną sprawą w SCM jest poprawa efektów w funkcjonowaniu przedsiębiorstwa (Ellinger $\mathrm{i}$ in., 2011) oraz wzrost satysfakcji odbiorców (Green i in., 2006). Dodatkowo zarządzanie łańcuchem odbiorców umożliwia identyfikację popytu i dzięki temu komunikację z dostawcami (Cambra-Fierro i Polo-Redondo, 2008), co przekłada się na przewidywanie dynamicznie zmieniającego się zachowania klientów oraz możliwości dopasowania się do trendów (Bustinza, Parry i Vendrell-Herrero, 2012; Holmström i in., 2010).

Przedsiębiorstwa $\mathrm{z}$ sektora high-tech wymagają w ramach relacji B2B, aby wspó1pracujące jednostki opierały się głównie na aspektach technologicznych (Weinstein, 2013). Oczekuje się przy tym również angażowania odbiorców $\mathrm{w}$ procesy innowacyjne poprzez współtworzenie wartości, dzięki wykorzystaniu koncepcji otwartej innowacji opartej na współpracy z klientami, dostawcami, a nawet konkurentami (Bain i Company, 2010).

\section{Metodyka badania 1}

W nauce często spotykamy się z sytuacją, gdy zmienna jest typu dychotomicznego $(0,1)$. Tego rodzaju zmienne moga występować $\mathrm{w}$ modelu $\mathrm{w}$ roli zmiennych zależnych i niezależnych. Jeżeli występuja w roli zmiennych objaśniających, to prognozowanie wartości zmiennej objaśnianej przebiega tak jak w liniowych modelach ekonometrycznych (Zeliaś, Pawełek i Wanat, 2004).

W przypadku, gdy zmienna zależna osiąga wartości dychotomiczne, nie można wykorzystać powszechnie stosowanej w zjawiskach ilościowych regresji wielorakiej. Wartości takiej funkcji mogą bowiem osiągać wartości ujemne lub wyższe od jedno- 
ści, a są one w prowadzonych badaniach pozbawione interpretacyjnego sensu. Rozwiązaniem tych problemów jest zastosowanie regresji logistycznej. Jej zaletą jest to, że analiza i interpretacja wyników jest podobna do klasycznej metody regresji. Posiada ona jednak również ograniczenia, do których możemy zaliczyć: bardziej skomplikowane i czasochłonne obliczenia czy wyliczanie wartości i sporządzanie wykresów reszt, często niewnoszące nic znaczącego do modelu (Stanisz, 2007).

Pionierami w stosowaniu krzywej logistycznej byli P.F. Verhulst i R.F. Pearl. Pełny model został zastosowany jednak po raz pierwszy dopiero przez J. Berksona w latach 1944 i 1953 (Berkson, 1944; Berkson, 1990). W przypadku modelu, w którym zmienna zależna osiąga wartość 0 lub 1, wartość oczekiwana zmiennej zależnej może być interpretowana jako warunkowe prawdopodobieństwo realizacji danego zdarzenia przy ustalonych wartościach zmiennych niezależnych.

Ogólnie ująwszy, regresja logistyczna jest matematycznym modelem, który możemy użyć w celu opisania wpływu kilku zmiennych $\mathrm{X}_{1}, \mathrm{X}_{2}, \ldots, \mathrm{X}_{\mathrm{k}}$ na dychotomiczną zmienna Y. Gdy wszystkie zmienne niezależne są jakościowe, model regresji logistycznej jest równoznaczny z modelem logliniowym. Dla opisania takiego zjawiska można posłużyć się również regresją probitową (Gruszczyński, Kluza i Winek, 2003).

Wspólne założenia dla tych modeli są następujące (Lipiec-Zajchowska, 2003):

- dane pochodzą z próby losowej,

- $Y$ może przyjmować tylko dwie wartości: 0 lub 1 ,

- kolejne wartości $Y$ są statystycznie niezależne od siebie,

- prawdopodobieństwo, że $\mathrm{Y}=1$ zdefiniowane jest przez NCD (rozkład normalny) dla modelu probit lub LCD (rozkład logistyczny) dla modelu logit,

- nie występuje idealna zależność liniowa pomiędzy zmiennymi $X_{i}$ (założenie o braku współliniowości zmiennych niezależnych).

Zależność między wartościami Logit i Probit:

$$
\frac{\text { Logit }}{\text { Probit }}=\frac{\pi}{\sqrt{3}}=1,8
$$

Szacowanie parametrów w metodach ze zmienną dychotomiczną dokonuje się za pomocą metody największej wiarygodności. Zgodnie z jej zasadami poszukuje się wektora parametrów $a_{(k)}{ }^{M L}$, który gwarantuje największe prawdopodobieństwo otrzymania wartości zaobserwowanych $\mathrm{w}$ próbie (Welfe, 1998). Pomimo dość skomplikowanej procedury MNW zyskała popularność - można ją bowiem stosować w przypadku szerokiej gamy modeli, m.in. o zmiennych parametrach, ze złożoną strukturą opóźnień, heteroskedastycznych, a także nieliniowych. Własności MNW również w małych próbach sa w wielu przypadkach lepsze od innych, konkurencyjnych estymatorów (Welfe, 1998).

W niniejszej pracy zastosowano podejście dualne. W przypadku oceny wpływu typu odbiorcy na zachowania innowacyjne badanych przedsiębiorstw posłużono się modelowaniem probitowym (modele jednoczynnikowe), które pozwoliło precyzyjnie określić szanse (prawdopodobieństwo) analizowanych zjawisk $\mathrm{w}$ dwóch przeciwstawnych grupach podmiotów. W zakresie oceny wpływu całego zbioru zmiennych niezależnych (typów odbiorców) na wybrane parametry innowacyjne wykorzystano modelownie logitowe (modele wieloczynnikowe), które $\mathrm{z}$ kolei umożliwiło wygenerowanie ilorazów szans i w konsekwencji sumaryczne porównanie siły wpływu poszczególnych zmiennych niezależnych w obrębie modelu, jak również między nimi.

W obrębie modelu badawczego do grupy zmiennych niezależnych zaliczono sektory gospodarki według sekcji PKD stosowanej przez Główny Urząd Statystyczny, czyli rolnictwo i rybactwo, górnictwo, przemysł, energetyka, budownictwo, handel, transport, gastronomia, finanse i ubezpieczenia, sferę publiczną, edukację, ochronę zdrowia, rozrywkę i rekreację. Zostały one dodatkowo wzbogacone o odpowiedź ukierunkowaną na konsumenta finalnego. Zgodnie $\mathrm{z}$ metodologią stosowaną przez wszystkie kraje OECD (OECD, 2005) do zmiennych zależnych zaliczono natomiast: wielkość i strukturę nakładów na działalność innowacyjną, wdrożenia nowych produktów i procesów, a także współpracę w obszarze nowych technologii wraz $\mathrm{z}$ ich strukturą podmiotową. W konsekwencji oszacowano blisko trzysta probitowych modeli jednoczynnikowych, z których jedynie część uzyskała istotność statystyczną. Ze względu na objętość materii zdecydowano się tylko na ogólną prezentację wniosków 
dla całej zbiorowości (początek kolejnego paragrafu) oraz szczegółowe przybliżenie dwóch skrajnych grup, czyli odbiorcy finalnego oraz odbiorcy przemysłowego. Na końcu pracy uwzględniono wzajemne interakcje występujące między zmiennymi niezależnymi, czego konsekwencją jest wieloczynnikowy model logitowy, który dostarcza dodatkowych i systemowych możliwości interpretacyjnych.

\section{Typ odbiorcy a aktywność innowacyjna przemysłu w Polsce - modele cząstkowe}

Przeprowadzone analizy koncentruja się na prezentacji oraz wnioskach, które zostały sformułowane dla dwóch przeciwstawnych typów odbiorców - użytkownika finalnego lub pośrednika $\mathrm{z}$ obszaru przetwórstwa przemysłowego. Szczegółowe analizy zostały zrealizowane jednak dla wszystkich grup odbiorców w łańcuchu dostaw, zgodnie z obowiązującą klasyfikacją sektorów gospodarki prowadzoną przez GUS (PKD). Biorąc to pod uwagę, najwięcej modeli $\mathrm{z}$ parametrami istotnymi statystycznie (jednoczynnikowe modelowanie probitowe) oraz pozytywnym oddziaływaniem oszacowano dla:

- przetwórstwa przemysłowego (17 modeli, w tym 16 ze znakiem dodatnim),

- transportu i automotive (17 modeli, w tym 17 ze znakiem dodatnim),

- energetyki (15 modeli, w tym 15 ze znakiem dodatnim),

- budownictwa (14 modeli, w tym 14 ze znakiem dodatnim),

- górnictwa i kopalnictwa (12 modeli, w tym 12 ze znakiem dodatnim),

- ochrony zdrowia (9 modeli, w tym 9 ze znakiem dodatnim)

- rolnictwa, rybołówstwa (7 modeli, w tym 7 ze znakiem dodatnim),

- gastronomii (7 modeli, w tym 6 ze znakiem dodatnim),

- handlu (6 modeli, w tym 5 ze znakiem dodatnim),

- sportu i rekreacji oraz finansów i ubezpieczeń (po 5 modeli, w tym 5 ze znakiem dodatnim),

- edukacji (4 modele, w tym 4 ze znakiem dodatnim),

- sfery publicznej (3 modele, w tym 3 ze znakiem dodatnim).

Głównym reprezentantem dla wyżej wskazanych działów gospodarki staje się tym samym przetwórstwo przemysłowe. $\mathrm{Z}$ perspektywy systemowej widzimy jednocześnie, że sfera publiczna (zamówienia publiczne) to jedno $\mathrm{z}$ najsłabszych ogniw $\mathrm{w}$ stymulowaniu innowacji w przemyśle krajowym. Odbiorca tego typu, pomimo znacznej siły oddziaływania na procesy gospodarcze (wartość zamówień publicznych) $w$ niewielkim stopniu wpływa na akcelerację procesów innowacyjnych, co nie jest zgodne $\mathrm{z}$ tendencjami obserwowanymi w zagranicznych źródłach literaturowych (Sekerin, 2014).

Gdy użytkownikiem wytwarzanych produktów jest odbiorca finalny, można zauważyć zupełnie inne zachowanie (tabela 2). W tym przypadku oszacowano dziesięć modeli. W dziewięciu $\mathrm{z}$ nich główny parametr osiągnął znak ujemny, wyjątkiem jest tu jedynie wprowadzanie nowych produktów. Oznacza to, że podmioty przemysłowe zlokalizowane w Polsce, produkujące wyroby dla ostatecznego konsumenta, rzadziej realizują działania innowacyjne (poza nowymi wyrobami) niż przedsiębiorstwa mające inne typy użytkowników.

Podmioty przemysłowe w Polsce, które dostarczają swoje produkty końcowemu konsumentowi, są statystycznie rzadziej zainteresowane wdrażaniem różnych aspektów aktywności innowacyjnej, poza nowymi wyrobami. Presja konkurencji być może jest za słaba w otoczeniu badanych podmiotów, albo ich umiejętności asymilacji nowych technologii są zbyt małe. Razem budują one obraz niskiej dojrzałości systemowej przedsiębiorstw w możliwości wdrażania nowych technologii, które są gwarancją wysokiej konkurencyjności oferowanych produktów.

Odmienne zależności można zauważyć w sytuacji, gdy odbiorcą produktów wytwarzanych w krajowym przemyśle jest inny podmiot przemysłowy (tabela 3). Na osiemnaście potencjalnych zmiennych wyestymowano aż siedemnaście modeli istotnych statystycznie (brakuje modelu jedynie dla współpracy innowacyjnej z konkurentami), w tym tylko w jednym przypadku parametr ma znak ujemny - nowe produkty.

Szansa na prowadzenie działalności $\mathrm{B}+\mathrm{R}$ jest wyższa o $56,2 \%$, a dla inwestycji o $12,2 \%$, w tym nowych budynków o $52,2 \%$, maszyn i urządzeń o 15,4\% oraz oprogramowania komputerowego o 29,8\%. Gdy użytkownikiem ostatecznym jest inny podmiot przemysłowy, nowe wyroby wdraża się 
Tabela 2. Modele jednoczynnikowe ze zmienną niezależną „sprzedaż finalnemu użytkownikowi”, w modelach probitowych opisujących innowacyjności przemysłu w Polsce (modele istotne statystyczne)

\begin{tabular}{|l|c|c|c|c|c|c|c|}
\hline \multicolumn{1}{|c|}{ Atrybut innowacyjności } & $\begin{array}{c}\text { Para- } \\
\text { metr }\end{array}$ & $\begin{array}{c}\text { Błąd } \\
\text { standar- } \\
\text { dowy }\end{array}$ & $\begin{array}{c}\text { Test } \\
\text { Walda }\end{array}$ & $\begin{array}{c}\text { Chi- } \\
\text { kwa- } \\
\text { drat }\end{array}$ & $\mathbf{P}>|\mathbf{z}|$ & $\mathbf{p}_{\mathbf{1}}$ & $\mathbf{p}_{\mathbf{2}}$ \\
\hline Nakłady na działalność B+R &,- 192 & 0,0360 & $-5,348$ & 28,60 & 0,00 & 0,32 & 0,39 \\
\hline $\begin{array}{l}\text { Inwestycje w dotychczas } \\
\text { niestosowane (w tym): } \\
\text { a) nowe budynki i budowle }\end{array}$ &,- 120 & 0,0380 & $-3,160$ & 9,94 & 0,00 & 0,74 & 0,77 \\
\cline { 2 - 9 } &,- 210 & 0,0380 & $-5,480$ & 30,29 & 0,00 & 0,22 & 0,28 \\
\hline Oprogramowanie komputerowe &,- 237 & 0,0355 & $-6,680$ & 44,63 & 0,00 & 0,56 & 0,65 \\
\hline Nowe wyroby &,+ 114 & 0,0350 & 3,260 & 10,53 & 0,00 & 0,58 & 0,53 \\
\hline Procesy technologiczne &,- 096 & 0,0370 & $-2,560$ & 6,57 & 0,01 & 0,71 & 0,74 \\
\hline Współpraca z PAN &,- 202 & 0,0920 & $-2,190$ & 4,96 & 0,03 & 0,01 & 0,02 \\
\hline Współpraca ze szkołami wyższymi &,- 314 & 0,0650 & $-4,800$ & 23,98 & 0,00 & 0,03 & 0,06 \\
\hline Współpraca z krajowymi JBR-ami &,- 229 & 0,0520 & $-4,420$ & 19,86 & 0,00 & 0,06 & 0,10 \\
\hline Współpraca innowacyjna ogółem &,- 188 & 0,0350 & $-5,340$ & 28,47 & 0,00 & 0,39 & 0,46 \\
\hline
\end{tabular}

$\mathrm{p}_{1}$ - prawdopodobieństwo wystąpienia danego zjawiska w badanej grupie przedsiębiorstw

$\mathrm{p}_{2}$ - prawdopodobieństwo wystąpienia danego zjawiska w pozostałej grupie przedsiębiorstw

Źródło: opracowanie własne na podstawie autorskich badań ankietowych.

o $8,9 \%$ rzadziej, ale już nowe procesy technologiczne o $11,4 \%$ częściej, w tym bezpośrednio produkcyjne o $26,7 \%$, systemy okołoprodukcyjne o $25,8 \%$ i wsparcia o $50,0 \%$. W zakresie kooperacji innowacyjnej także można zauważyć silne, jednokierunkowe i pozytywne tendencje. Szanse absolutne na współpracę ze sferą nauki są jednak bardzo niskie.

Organizacje, które są pośrednim ogniwem dostaw przemysłowych częściej realizują aktywność innowacyjną niż te, które działają na rynku detalicznym. Prawidłowości te mają charakter systemowy i dotycza wszystkich poza jedną rozpatrywaną płaszczyzna odniesienia (nowych wyrobów). Zjawisko to jest silne i powszechne, a przedsiębiorstwa te osiągnęły wysoką zdolność konkurencyjną, działając często na rzecz odbiorcy przemysłowego funkcjonującego na rynku międzynarodowym. Procesy tam generowane mają charakter popytowy i związane są z wysokimi wymogami jakościowo-ilościowych konsumentów. Można postawić tezę, iż podmioty przemysłowe funkcjonujące w Polsce na tym etapie rozwoju nie są w stanie konkurować na rynku z bardziej doświadczonymi, rozwiniętymi technologicznie przedsiębiorstwami, lecz mogą wiele się od nich nauczyć, wchodząc z nimi we wspólpracę produkcyjną. Nasz kraj znajduje się na etapie określanym jako zależność technologiczna wymuszona przez odbiorców przemysłowych, z niewielkimi szansami na zmianę sytuacji w kierunku strategii naśladowczej w najbliższej przyszłości, nie wspominając o defensywnej.

\section{Typy odbiorców a aktywność innowacyjna przemysłu w Polsce - model systemowy}

Po analizie modeli jednoczynnikowych zdecydowano się na próbę uwzględnienia systemowych interakcji między zmiennymi niezależnymi. Na początkowym etapie wykorzystano metodę regresji wielokrotnej krokowej brzegowej postępującej i zidentyfikowano zmienne, które spełniają kryterium istotności statystycznej. $\mathrm{Na}$ tej podstawie wybrane zmienne przeniesiono do regresji logistycznej, za pomocą której określono ilorazy szans występowania działalności innowacyjnej, wykluczając albo mocno ograniczając występowanie autokorelacji między zmiennymi niezależnymi. Wartość addytywna takiego podejścia to możliwość zestawienia oraz komparatystyki 
Tabela 3. Modele jednoczynnikowe ze zmienną niezależną „odbiorca przemysłowy”, w modelach probitowych opisujących innowacyjności przemysłu w Polsce (modele istotne statystyczne)

\begin{tabular}{|l|r|c|c|c|c|c|c|}
\hline \multicolumn{1}{|c|}{ Atrybut innowacyjności } & $\begin{array}{c}\text { Para- } \\
\text { metr }\end{array}$ & $\begin{array}{c}\text { Błąd } \\
\text { standar- } \\
\text { dowy }\end{array}$ & $\begin{array}{c}\text { Test } \\
\text { Walda }\end{array}$ & $\begin{array}{c}\text { Chi- } \\
\text { kwa- } \\
\text { drat }\end{array}$ & $\mathbf{P}>|\mathbf{z}|$ & $\mathbf{p}_{\mathbf{1}}$ & $\mathbf{p}_{\mathbf{2}}$ \\
\hline Nakłady na działalność B+R &,+ 474 & 0,0425 & 11,14 & 124,03 & 0,00 & 0,50 & 0,32 \\
\hline $\begin{array}{l}\text { Inwestycje w dotychczas } \\
\text { niestosowane (w tym): } \\
\text { a) nowe budynki i budowle } \\
\text { b) w maszyny i urząadzenia } \\
\text { techniczne }\end{array}$ &,+ 339 & 0,0490 & 6,90 & 49,28 & 0,00 & 0,83 & 0,74 \\
\cline { 2 - 9 } &,+ 338 & 0,0440 & 7,67 & 58,07 & 0,00 & 0,35 & 0,23 \\
\cline { 2 - 9 } &,+ 276 & 0,0450 & 6,11 & 37,91 & 0,00 & 0,75 & 0,65 \\
\hline Oprogramowanie komputerowe &,+ 476 & 0,0450 & 10,56 & 115,23 & 0,00 & 0,74 & 0,57 \\
\hline Nowe wyroby &,- 119 & 0,0420 & $-2,81$ & 7,89 & 0,00 & 0,51 & 0,56 \\
\hline $\begin{array}{l}\text { Procesy technologiczne, w tym: } \\
\text { a) procesy produkcyjne } \\
\text { b) systemy okołoprodukcyjne } \\
\text { c) systemy wsparcia }\end{array}$ &,+ 360 & 0,0480 & 7,51 & 58,37 & 0,00 & 0,82 & 0,70 \\
\cline { 2 - 9 } &,+ 301 & 0,0420 & 7,11 & 50,77 & 0,00 & 0,57 & 0,45 \\
\cline { 2 - 9 } &,+ 230 & 0,0430 & 5,35 & 28,45 & 0,00 & 0,39 & 0,31 \\
\cline { 2 - 9 } &,+ 334 & 0,0440 & 7,51 & 55,71 & 0,00 & 0,33 & 0,22 \\
\hline Współpraca z dostawcami &,+ 241 & 0,0440 & 5,45 & 29,45 & 0,00 & 0,32 & 0,24 \\
\hline Współpraca z PAN &,+ 267 & 0,0950 & 2,80 & 7,45 & 0,01 & 0,02 & 0,01 \\
\hline Współpraca ze szkołami wyższymi &,+ 562 & 0,0650 & 8,68 & 72,12 & 0,00 & 0,09 & 0,03 \\
\hline Współpraca z krajowymi JBR-ami &,+ 437 & 0,0550 & 7,93 & 60,65 & 0,00 & 0,14 & 0,07 \\
\hline $\begin{array}{l}\text { Współpraca z zagranicznymi } \\
\text { jednostkami nauki }\end{array}$ &,+ 290 & 0,0870 & 3,31 & 10,45 & 0,00 & 0,03 & 0,02 \\
\hline Współpraca z odbiorcami &,+ 385 & 0,0450 & 8,52 & 71,66 & 0,00 & 0,30 & 0,19 \\
\hline Współpraca innowacyjna ogółem &,+ 413 & 0,0430 & 9,72 & 95,19 & 0,00 & 0,56 & 0,40 \\
\hline
\end{tabular}

$\mathrm{p}_{1}$ - prawdopodobieństwo wystąpienia danego zjawiska $\mathrm{w}$ badanej grupie przedsiębiorstw $\mathrm{p}_{2}$ - prawdopodobieństwo wystąpienia danego zjawiska w pozostałej grupie przedsiębiorstw

Źródło: opracowanie własne na podstawie autorskich badań ankietowych.

jednocześnie wszystkich grup odbiorców, zarówno w pionie (w obrębie modelu), jak i poziomie (pomiędzy modelami).

Zdołano wyestymować pięć wieloczynnikowych modeli istotnych $\mathrm{z}$ perspektywy badania, opisujących aktywność innowacyjną przez pryzmat działalności $\mathrm{B}+\mathrm{R}$, maszyn i urządzeń, nowych produktów i procesów technologicznych oraz współpracy innowacyjnej. Wszystkie modele osiągnęły wysokie stopnie istotności, jednak sa wewnętrznie zróżnicowane jeżeli chodzi o wpływ typu użytkownika na procesy innowacyjne.

Można na początku dostrzec dwie grupy prawidłowości. Pierwsza jest związana $\mathrm{z}$ nowymi produktami, a druga $-\mathrm{z}$ pozo- stałymi działaniami innowacyjnymi łącznie. Podmioty, w których wdrożono produkcję nowych wyrobów, najczęściej działają na rzecz sektora rozrywki i rekreacji (szanse wyższe o $35,7 \%$ ). Istotnymi odbiorcami są podmioty funkcjonujące $\mathrm{w}$ energetyce (o 31,6\%), sektor publiczny (o 24,1\%), handel $(20,5 \%)$, konsument krańcowy $(19,9 \%)$ i gastronomia $(17,2 \%)$. Powyższe grupy odbiorców pozytywnie wpływają na wprowadzanie nowych wyrobów w badanych podmiotach przemysłowych. Inne łącznie obniżają możliwości realizacji takiego rozwiązania o $6,4 \%$ (wyraz wolny), ale najsilniej, jeżeli działają na rzecz sektora finansowo-ubezpieczeniowego. Wtedy prawdopodobieństwo kreowania nowych 
Tabela 4. Zależność między typem odbiorcy a kluczowymi obszarami aktywności innowacyjnej przemysłu w Polsce - wieloczynnikowe modelowanie logitowe

\begin{tabular}{|c|c|c|c|c|c|}
\hline Zmienna & $\mathbf{B}+\mathbf{R}$ & $\begin{array}{c}\text { Maszyny } \\
\text { i urządzenia }\end{array}$ & $\begin{array}{l}\text { Nowe } \\
\text { wyroby }\end{array}$ & $\begin{array}{l}\text { Nowe } \\
\text { procesy }\end{array}$ & $\begin{array}{l}\text { Współpraca } \\
\text { innowacyjna }\end{array}$ \\
\hline Górnictwo & $\begin{array}{c}1,281 \\
(* *)\end{array}$ & ------ & ------ & ------ & $\begin{array}{c}1,337 \\
(* *)\end{array}$ \\
\hline Przemysł & $\begin{array}{l}1,868 \\
(* * *)\end{array}$ & $\begin{array}{l}1,411 \\
(* * *)\end{array}$ & ------ & $\begin{array}{l}1,802 \\
(* * *) \\
\end{array}$ & $\begin{array}{l}1,685 \\
(* * *)\end{array}$ \\
\hline Energetyka & $\begin{array}{l}1,660 \\
(* * *)\end{array}$ & $\begin{array}{l}1,668 \\
(* * *)\end{array}$ & $\begin{array}{c}1,316 \\
(* *) \\
\end{array}$ & $\begin{array}{l}1,500 \\
(* * *) \\
\end{array}$ & $\begin{array}{l}1,435 \\
(* * *)\end{array}$ \\
\hline Budownictwo & $\begin{array}{l}1,211 \\
(* * *)\end{array}$ & $\begin{array}{l}1,429 \\
(* * *)\end{array}$ & ------ & $\begin{array}{l}1,448 \\
(* * *) \\
\end{array}$ & $\begin{array}{c}1,171 \\
(* *)\end{array}$ \\
\hline Handel & ------ & ------ & $\begin{array}{l}1,205 \\
(* * *)\end{array}$ & $\begin{array}{l}1,430 \\
(* * *)\end{array}$ & $\begin{array}{c}1,132 \\
(* *)\end{array}$ \\
\hline Transport & $\begin{array}{l}1,317 \\
(* * *)\end{array}$ & $\begin{array}{c}1,239 \\
(* *) \\
\end{array}$ & ------ & $\begin{array}{l}1,329 \\
(* * *)\end{array}$ & $\begin{array}{l}1,317 \\
(* * *)\end{array}$ \\
\hline Gastronomia & ------ & ------ & $\begin{array}{c}1,172 \\
(* *)\end{array}$ & ----- & ------ \\
\hline $\begin{array}{l}\text { Finanse } \\
\text { i ubezpieczenia }\end{array}$ & ------ & ------ & $\begin{array}{c}0,737 \\
(* *)\end{array}$ & ------ & ------ \\
\hline Sfera publiczna & ------ & ------ & $\begin{array}{l}1,241 \\
(* * *) \\
\end{array}$ & ----- & ------ \\
\hline Ochrona zdrowia & $\begin{array}{l}1,373 \\
(* * *)\end{array}$ & ------ & ------ & ------ & $\begin{array}{c}1,309 \\
(* *)\end{array}$ \\
\hline Rozrywka i rekreacja & ------ & ------ & $\begin{array}{l}1,357 \\
(* * *) \\
\end{array}$ & $\begin{array}{r}1,532 \\
(* * *)\end{array}$ & ------ \\
\hline Konsument końcowy & ------ & ------ & $\begin{array}{l}1,199 \\
(* * *)\end{array}$ & ------ & $\begin{array}{c}0,884 \\
(* *)\end{array}$ \\
\hline Stała & $\begin{array}{l}0,408 \\
(* * *)\end{array}$ & $\begin{array}{l}1,671 \\
(* * *)\end{array}$ & $\begin{array}{l}0,936 \\
(* * *) \\
\end{array}$ & $\begin{array}{l}1,695 \\
(* * *) \\
\end{array}$ & $\begin{array}{l}0,584 \\
(* * *)\end{array}$ \\
\hline Wielkość próby & 5209 & 5209 & 5209 & 5209 & 5209 \\
\hline Chi2 & 193,32 & 94,929 & 58,892 & 156,13 & 158,39 \\
\hline Wartość p & 0,00 & 0,00 & 0,00 & 0,00 & 0,00 \\
\hline
\end{tabular}

$(* * *)$ - istotność na poziomie $1 \%,(* *)$ - istotność na poziomie $5 \%,(*)$ - istotność na poziomie $10 \%$.

Źródło: opracowanie własne na podstawie autorskich badań ankietowych.

wyrobów spada o 0,26 pp. Przedsiębiorstwa przemysłowe oferują nowe produkty na silnie zdywersyfikowanych rynkach, które w niewielkim zakresie powiązane są $\mathrm{z}$ przemysłem.

Ze wszystkich rozważanych obszarów aktywności innowacyjnej najsilniej zdeterminowana typem odbiorcy jest działalność $\mathrm{B}+\mathrm{R}$. Jest ona prowadzona $\mathrm{w}$ przedsiębior- stwach produkujących dla innych sektorów gospodarki. Najczęściej w B+R inwestują organizacje, dla których odbiorca jest przetwórczość przemysłowa. Aby realizować działania w sferze $B+R$, badane przedsiębiorstwa powinny być pośrednim ogniwem w przemysłowym łańcuchu dostaw. Szanse na takie działania rosną wtedy o 86,6\% $\mathrm{i}$ jest to najwyższy iloraz ze wszystkich wyestymo- 
wanych modeli. Ważnym i mocnym stymulatorem do angażowania się $\mathrm{w}$ działalność $\mathrm{B}+\mathrm{R}$ mogą być również odbiorcy z sektora energetycznego (wzrost szans o 37,3\%), ochrony zdrowia (o 37,3\%), transportowego i automotive (o 31,7\%), górnictwa (o $28,1 \%$ ) i budownictwa (o 21,2\%). Bierny transfer technologii, związany $\mathrm{z}$ zakupem maszyn i urządzeń, wywołuje podobne prawidłowości jak w przypadku sfery $\mathrm{B}+\mathrm{R}$. Skłonność do kupowania nowoczesnych środków produkcji rośnie w przypadku, gdy klientem wytwarzanych produktów jest sektor energetyczny (wzrost o 66,8\%), budownictwo (o 42,9\%), przetwórstwo przemysłowe (o 41,1\%) i transport oraz automotive $(23,9 \%)$. Nowe procesy technologiczne są silnie i pozytywnie determinowane typem klientów w badanych jednostkach przemysłowych. Wytwórczość przemysłowa jest ponownie najsilniejszym stymulatorem i zwiększa szanse o 80,2\% na wdrażanie nowych technologii. Ważnym warunkiem kreowania nowych technologii w Polsce jest produkcja na rzecz innych przedsiębiorstw przemysłowych. Koniecznie trzeba jednak zauważyć, iz szanse na takie wdrożenie są także wysokie w pozostałych przedsiębiorstwach.

Uzyskane wyniki badań można zinterpretować horyzontalnie i wtedy nasuwa się wniosek, że najczęściej do działalności innowacyjnej przyczyniają się klienci z sektora energetycznego, ale najsilniej z przetwórstwa przemysłowego. Wspomagani są odbiorcami z obszaru transportu i automotive, budownictwa, a następnie handlu, rozrywki i rekreacji, ochrony zdrowia oraz górnictwa. Negatywny wpływ występuje ze strony sektora finansów i ubezpieczeń (nowe wyroby), a także w sytuacji, kiedy klient jest jednocześnie użytkownikiem finalnym (współpraca innowacyjna).

Reasumując: modele wieloczynnikowe pokazały zagregowany i różnokierunkowy wpływ wybranych typów klientów na kluczowe obszary aktywności innowacyjnej w krajowym przemyśle. Zidentyfikowano specyfikę oraz pośrednio stan zaawansowania i dojrzałości technologicznej badanych podmiotów, co może być podstawą do formułowania wniosków. Po pierwsze, charakter odbiorcy silnie determinuje procesy innowacyjne w polskim systemie przemysłowym. Po drugie, zbliżone wyniki zostały uzyskane dla poszczególnych atrybutów innowacyjności, jak aktywne tworzenie technologii, pasywny jej transfer, wprowadzanie nowych procesów oraz współpraca z tym związana, a odmienne dla nowych produktów. Trzeba jednak zauważyć, że ostatnie lata wskazują, iż w Polsce nowa wiedza jest częściej implementowana do procesów produkcyjnych, niż wyrobów, co można potwierdzić danych GUS (GUS, 2015). Po trzecie, w krajowym przemyśle działalność innowacyjna jest realizowana wtedy, gdy ten działa na rzecz innych przedsiębiorstw przemysłowych. Badane jednostki powinny zatem funkcjonować jako poddostawca dla innych podmiotów w ramach przemysłowego łańcucha dostaw. Jest to najsilniejszy zaobserwowany czynnik, który odpowiada za akcelerację procesów innowacyjnych w Polsce. Istotną, ale mniej ważną rolę odgrywają klienci z sektora rozrywki i rekreacji, ochrony zdrowia, transportu i automotive oraz budownictwa. Po czwarte, najwyższe ilorazy szans zostały osiągnięte dla działalności B+R, co jednoznacznie pokazuje, że w Polsce ta aktywność koncentruje się i jest silnie zdeterminowana typem odbiorcy. Jednocześnie poza przemysłem, budownictwem, transportem i ochroną zdrowia aktywność badawczorozwojowa jest bardzo słaba. Wsparcie powinno koncentrować się zatem na wskazanych grupach (polityka selektywna).

\section{Podsumowanie}

Przeprowadzone analizy probitowa i logitowa dały wiele wzajemnych, koherentnych oraz interesujących wniosków dotyczących wpływu typu odbiorcy na zachowania innowacyjne przemysłu w Polsce. Wskazują one na to, gdzie szukać silnych stron badanych podmiotów, na jakim etapie rozwoju się one znajdują, w jakim kierunku podążają (ewolucja systemowa), gdzie koncentrować wsparcie. Dzięki nim można również wskazać stopień dyferencjacji krajowych warunków gospodarowania w odniesieniu do bardziej rozwiniętych państw, a tym samym nieadekwatność zastosowania tych samych mechanizmów akceleracji procesów technologicznych.

W polskim przemyśle aktywność innowacyjna jest silnie zdeterminowana charakterystyką klientów, co może świadczyć o występowaniu popytowego modelu procesów tworzenia nowych technologii w badanych podmiotach. Zaobserwowane tendencje dotyczą finansowania, imple- 
mentacji nowych rozwiązań, a także kooperacji z nimi związanej.

Analiza probitowa pozwoliła na ukazanie dwóch skrajnie odmiennych interakcji, które można zaobserwować w polskim przemyśle. Po pierwsze, gdy odbiorca dla badanych przedsiębiorstw jest finalny użytkownik, wtedy szanse rozwijania nowych technologii maleją (poza nowymi produktami). Druga sytuacja ukazująca przeciwne zjawisko jest wtedy, gdy rozpatruje sie relacje z odbiorcą przemysłowym. Wówczas aktywność innowacyjna intensywnie rośnie. Krajowy przemysł, który występuje w roli ostatecznego ogniwa dostaw, okazuje się zatem mało innowacyjny. Gdy jest pośrednim elementem w łańcuchu, wtedy intensywność innowacyjna szybko rośnie. Swiadczy to o tym, że polski system przemysłowy nie osiągnął jeszcze dojrzałości technologicznej, która mogłaby być porównywalna $\mathrm{z}$ innymi krajami.

Modelowanie logitowe, przeprowadzone dla całego systemu przemysłowego, pozwoliło na wyciągnięcie wniosków potwierdzających silne oparcie innowacyjne polskich organizacji na odbiorcach przemysłowych. Wszechobecna skala negatywnego oddziaływania użytkownika końcowego nie uzyskała jednak potwierdzenia. Przedsiębiorstwa wprowadzające nowe produkty maja znacznie bardziej zróżnicowanych odbiorców, choć siła ich pozytywnego wpływu nie jest aż tak silna jak w innych aspektach działalności innowacyjnej.

Najszybszy wzrost szans na nowe technologie występuje wtedy, gdy odbiorcy analizowanych jednostek gospodarczych należą do przetwórstwa przemysłowego, energetyki, budownictwa, sektora transportowego i autmotive, handlu, górnictwa i ochrony zdrowia. Biorąc jednakże pod uwagę rodzaje aktywności innowacyjnej, to wysokie szanse można zauważyć dla sfery $\mathrm{B}+\mathrm{R}$, nowych procesów technologicznych, stosowania nowych maszyn i urządzeń czy współpracy innowacyjnej. Kategoria nowych produktów nie jest zbieżna z tym trendem. Polityka innowacyjna powinna zatem w tej dziedzinie skupiać się na organizacjach, które są podwykonawcami dla innych przedsiębiorstw, w tym przede wszystkim szeroko pojętego przemysłu. Pozytywnie oceniona została również rola przemysłu realizującego produkcję na rzecz sektora ochrony zdrowia.

Podsumowując: hipoteza postawiona na początku opracowania nie została zwery- fikowana pozytywnie. Pomimo że badane podmioty dystrybuują swoje produkty głównie ostatecznemu klientowi, ich aktywność innowacyjna jest niska. Ich umiejętności asymilacyjne wiedzy nie są wystarczające, natomiast zmiany stosowanych technologii często wymuszone przez głównego użytkownika, szczególnie odbiorcę przemysłowego. Aktualne zaawansowanie technologiczne przedsiębiorstw w Polsce utrudnia im zatem skuteczne konkurowanie na rynku zagranicznym. Krajowa polityka innowacyjna powinna koncentrować się na organizacjach, które są pośrednim ogniwem w łańcuchu dostaw. Należy przy tym prowadzić dalsze badania nad przyczynami niskiej innowacyjności przedsiębiorstw tworzących rozwiązania skierowane dla ostatecznego użytkownika.

\section{Przypis}

1 Ze względu na stricte i w całości odtwórczy charakter zastosowanej metodologii ekonometrycznej autorzy postanowili przytoczyć wcześniej opublikowane fragmenty prac A. Świadka (Świadek, 2011; Świadek, 2008), wzbogaconych o specyfikę wynikającą z prezentowanej materii badawczej.

\section{Bibliografia}

Adler, P.S. (1995). Interdepartmental interdependence and coordination: The case of the design/ manufacturing interface. Organization Science, 6(2), 147-167. http://dx.doi.org/10.1287/orsc.6.2.147

Aghion, P. i Jaravel, X. (2015). Knowledge Spillovers, Innovation and Growth. The Economic Journal, 125(583), 533-573. http://dx.doi.org/10.1111/ ecoj.12199

Anderson, E.W., Fornell, C. i Lehmann, D.R. (1994). Customer satisfaction, market share, and profitability: Findings from Sweden. The Journal of Marketing, 58(3), 53-66.

Bain \& Company (2013). Open Innovation, Management Tools 2011, 8 maja. Pozyskano z: http:// www.bain.com/publications/articles/managementtools-open-innovation.aspx (8.04. 2015).

Berkson, J. (1944). Application of the logistic function to bio-assay. Journal of American Statistic Association, 39, 357-365.

Berkson, J. (1990). Maximum likelihood in the Pharmaceutical Science. New York: Marcel Dekker.

Boaz, N., Murnane, J. i Nuffer, K. (2010). The Basics of Business-toBusiness sale success. Pozyskano z: www.mckinsey.com

Bustinza, O.F., Parry, G. i Vendrell-Herrero, F. (2013). Supply and demand chain management: 
The effect of adding services to product offerings. Supply Chain Management: An International Journal, 18(6), 618-629. http://dx.doi.org/10.1108/SCM05-2013-0149

Cambra-Fierro, J.J. i Polo-Redondo, Y. (2008). Creating satisfaction in the demand-supply chain: the buyers' perspective. Supply Chain Management: An International Journal, 13(3), 211-24. http:// dx.doi.org/10.1108/13598540810871253

Christopher, M. (2005). Logistics and Supply Chain Management: Creating Value-Adding Networks. NY: Pearson Education.

Dixon, M. i Adamson, B. (2012). The One Kind of Sales Rep Who Does Best at B2B. Forbes. Pozyskano z: www.forbes.com

Ellinger, A., Shin, H., Northington, W.M., Adams, F.G., Hofman, D. i O’Marah, K. (2012). The influence of supply chain management competency on customer satisfaction and shareholder value. Supply Chain Management: An International Journal, 17(3), 249-262. http://dx.doi. org/10.1108/13598541211227090

Faems, D., Van Looy, B. i Debackere, K. (2005). Interorganizational collaboration and innovation: toward a portfolio approach*. Journal of product innovation management, 22(3), 238-250. http:// dx.doi.org/10.1111/j.0737-6782.2005.00120.x

Gemünden, H.G., Ritter, T. i Heydebreck, P. (1996). Network configuration and innovation success: An empirical analysis in German high-tech industries. International Journal of Research in Marketing, 13(5), 449-462, http://dx.doi.org/10.1016/ S0167-8116(96)00026-2

Geronikolaou G., Mourmouris I. (2015). On the Effect of Technological Gap on International Patenting: A Multi-Criteria Approach. British Journal of Economics, Management \& Trade, 6(4): 256-261.

Green, K.W., McGaughey, R. i Casey, K.M. (2006). Does supply chain management strategy mediate the association between market orientation and organizational performance?, Supply Chain Management: An International Journal, 11(5), 407-414. http://dx.doi.org/10.1108/ 13598540610682426

Griffin, A. i Hause, J.R. (1996). Integrating R\&D and marketing: a review and analysis of the literature. Journal of Product Innovation Management, 13(3), 191-215. http://dx.doi.org/10.1111/15405885.1330191

Gruszczyński, M., Kluza, S. i Winek, D. (2003). Ekonometria. Warszawa: WSHiFM.

Guo, C. i Wang, Y. (2015). How manufacturer market orientation influences B2B customer satisfaction and retention: empirical investigation of the three market orientation components. Journal of Business \& Industrial Marketing, 30(2), 182-193. http://dx.doi.org/10.1108/JBIM-03-2012-0042
GUS (2015). Bank danych lokalnych. Pozyskano z: www.stat.gov.pl (10.04.2015).

Hagedoorn, J. (1993). Understanding the rationale of strategic technology partnering: Interorganizational modes of cooperation and sectoral differences. Strategic Management Journal, 14(5), 371-385. http://dx.doi.org/10.1002/smj.4250140505

Holmström, J., Brax, S. i Ala-Risku T. (2010). Comparing provider-customer constellations of visibility-based service. Journal of Service Management, 21(5), 675-692. http://dx.doi.org/10.1108/ 09564231011079093

Kotler, P. (2003). Marketing management. International Edition. N.J.: Prentice Hall.

Laugen, B.T. i Lassen A.H. (2012). Collaborative innovation: Internal and external involvement in new product development. W: J. Frick i B.T. Laugen (red.), Advances in Production Management Systems. Value Networks: Innovation, Technologies, and Management (458-469). Springer Berlin Heidelberg. http://dx.doi.org/10.1007/978-3-642-33980-6_50

Lipiec-Zajchowska, M. (red.) (2003). Wspomaganie procesów decyzyjnych. Ekonometria. Warszawa: Wydawnictwo C.H. Beck.

Moore, G.A. i McKenna, R. (2006). Crossing the Chasm: Marketing and Selling High-Tech Products to Mainstream Customers. NY: Harper Business Essential.

OECD (2005), Podręcznik Oslo. Zasady gromadzenia i interpretacji danych dotyczacych innowacji. Wydanie trzecie. Paris.

Parry, G., Bustinza, O.F. i Vendrell-Herrero, F. (2012). Servitisation and value coproduction in the UK music industry: an empirical study of consumer attitudes. International Journal of Production Economics, 135(1): 320-332. http://dx.doi.org/10.1016/j. ijpe.2011.08.006

Powell, W.W., Koput, K.W. i Smith-Doerr, L. (1996). Interorganizational collaboration and the locus of innovation: Networks of learning in biotechnology. Administrative Science Quarterly, 41(6), 116-145. http://dx.doi.org/10.2307/2393988

Rodrigues, L.C. i Riccardi, R. (2007). Inteligência Competitiva - nos negócios e organizações, Competitive Intelligence - in business and organizations. Maringá (PR): Unicorpore.

Rogers, E.M. (1983). Diffusion of Innovation. NY: The Free Press.

Rothwell, R. (1994). Issues in user-producer relations in the innovation process: the role of government. International Journal of Technology Management, 9(5), 629-649.

Sekerin, V.D., Avramenko S.A., Veselovsky, M.Y. i Aleksakhina, V.G. (2014). B2G Market: The Essence and Statistical Analysis. World Applied Sciences Journal, 31(6), 1104-1108. 
Stanisz, A. (2007). Przystępny kurs statystki. Tom 2. Kraków: Statsoft.

Suominen, V.M., Kytölä, J. i Naaranoja, M. (2015). Customer-oriented product development process in B2B industry. International Journal of Technology Marketing, 10(1), 47-66. http://dx.doi.org/10.1504/ IJTMKT.2015.066075

The Differences Between $B 2 B$ and $B 2 C$ Research (2013). B2B International, www.b2binternational.com von Hippe E., de Jong, J.P.J. i Flowers, S. (2012). Comparing Business and Household Sector Innovation in Consumer Products: Findings from a Representative Study in the United Kingdom. Man- agement Science, 58(9), 1669-1681. http://dx.doi. org/10.1287/mnsc.1110.1508

Weinstein, A. (2012). Superior Customer Value: Strategies for Winning and Retaining Customers, 3rd edition. Boca Raton: CRC Press.

Weinstein, A., Jin, Y. i Barrett, H. (2013). Strategic Innovation in B2B Technology Markets: A Need for a Process Perspective. Journal of Supply Chain and Operations Management, 11(1), 64.

Welfe, A. (1998). Ekonometria. Warszawa: PWE.

Zeliaś, A., Pawełek, B. i Wanat, S. (2004). Prognozowanie ekonomiczne. Teoria. Przyktady. Zadania. Warszawa: Wydawnictwo Naukowe PWN. 